\title{
STRATEGI PENGEMBANGAN EKONOMI RAKYAT DI PROVINSI PAPUA
}

\section{DEVELOPMENT STRATEGIES IN PAPUA ECONOMIC DEMOCRACY}

\author{
Muhamad Ismail \\ Pusat Penelitian Pemerintahan Umum dan Kependudukan \\ Badan Penelitian dan Pengembangan (BPP) Kementrian Dalam Negeri \\ Jl. Kramat Raya No. 132 - Senen, Jakarta \\ No. Telp.: (0967) 535334 \\ Email: ismailfolaimam@yahoo.co.id \\ Dikirim: 3 Februari 2015 Direvisi: 20 Juli 2015 Disetujui: 20 Agustus 2015
}

\begin{abstract}
Abstrak
Pengembangan ekonomi kerakyatan bertujuan untuk meningkatkan partisipasi masyarakat dalam berbagai aktivitas pembangunan khususnya di bidang ekonomi. Pengembangan ekomomi kerakyatan dengan memanfaatkan potensi Usaha Mikro Kecil Menengah selama ini belum memberikan dampak yang signifikan bagi kesejahteraan masyarakat. Tujuan studi untuk melihat sejauh mana pengembangan ekonomi kerakyatan di Provinsi Papua, dan merumuskan strategi pengembangan ekonomi kerakyatan di Provinsi Papua. Menggunakan analsis SWOT, menggunakan data primer dan sekunder. Hasil penelitian menunjukan pengembangan ekonomi kerakyatan di Provinsi Papua belum dapat dilaksanakan secara maksimal karena dipengaruhi oleh beberapa kelemahan dan kendala teknis lainnya seperti kekurangan modal usaha, peralatan yang masih sederhana, kualitas dan kuantitas produk yang rendah, sulitnya akses pasar dan lemahnya jiwa kewirausahaan khususnya bagi masyarakat/pelaku ekonomi rakyat asli Papua. Pengembangan ekonomi kerakyatan dapat dilakukan dengan memanfaatkan peran Usaha mikro dan menengah dan Koperasi/KUD karena masyarakat dengan mudah dapat dilibatkan dalam kedua wadah ekonomi tersebut. Pengembangan ekonomi kerakyatan dapat dilakukan dengan : Peningkatan kualitas dan kuantitas produk lokal agar dapat bersaing dengan pasar regional dan internasional, pemberian dana stimulan untuk modal usaha bagi para pelaku ekonomi rakyat dengan memanfaatkan dana OTSUS, dan APBN, Peningkatan SDM pertanian melalui dukungan sektor swasta (mitra usaha) dan permodalan dari lembaga perbankan. Untuk mengatasi kelemahan yang dimiliki dalam pengembangan ekonomi kerakyatan maka dapat dilakukan melalui: Meningkatan kuallitas SDM pelaku ekonomi rakyat melalui pendidikan non formal/pelatihan, pendidikan dan pelatihan yang berkelanjutan bagi para tenaga pendamping, pemberian modal usaha dan peralatan pertanian dengan memanfaatkan teknologi tepat guna (TTG), meningkatkan peran Usaha Mikro Kecil Menengah dan koperasi sampai ke seluruh kabupaten/kota, Pemanfatan dana program untuk kegiatan ekonomi produktif. Kebijakan pengembangan ekonomi kerakyatan memiliki peluang berupa meningkatkanya kualitas dan kuantitas produk lokal yang berdaya saing, masyarakat tidak selalu mengantungkan pada bantuan modal pemerintah, pelaku ekonomi kerakyatan tidak selamanya tergantung pada tenaga pendamping.
\end{abstract}

Kata Kunci: Pengembangan Ekonomi Kerakyatan, Kesejahteraan Masyarakat

\begin{abstract}
Based economic development aims to increase community participation in various development activities, especially in the economic field. Populist both economic development by exploiting the potential of Micro Small Medium Enterprises has not made a significant impact to the welfare of society. The purpose of the study to see how far the populist economic development in Papua, and formulate a strategy based economic development in the province of Papua. Using SWOT the analysis, using primary and secondary data. The results showed populist economic development in Papua province could not be implemented to the fullest because it is affected by several drawbacks and other technical constraints such as shortage of working capital, equipment is still modest, the quality and quantity of the product is low, the difficulty of access to markets and weak entrepreneurial spirit, especially for community / indigenous people of Papua economic actors. Based economic development can be done by utilizing the role of micro and medium-sized businesses and cooperatives / KUD because people could easily be involved in both the economic container. Based economic development can be done by: Increasing the quality and quantity of local products to compete with regional and international markets, giving stimulant fund for venture capital for the economic actors of the people by utilizing funds OTSUS, and the state budget, Improved HR agriculture
\end{abstract}


through private sector support (partners business) and capital of banking institutions. To overcome the weaknesses in the development of community economy, it can be done through: Boosting kuallitas SDM economic actors people through non-formal education / training, education and ongoing training for facilitators, provision of venture capital and agricultural equipment by utilizing appropriate technology (TTG ), increasing the role of Micro, Small and Medium Enterprises and co-operatives to all districts / cities, utilization of program funds for productive economic activities. Populist economic development policy has a chance in the form of increasing the quality and quantity of local products competitive, people do not always pocket on government capital assistance, populist economic actors do not always depend on the facilitators.

Keywords: Populist Economic Development, Public Welfare

\section{PENDAHULUAN}

Pembangunan nasional diarahkan pada tercapainya standar kualitas hidup masyarakat, baik tingkat kesejahteraannya maupun kesehatan dan pendidikan. Pembangunan ekonomi merupakan salah satu bagian dari pembangunan yang penting bagi masyarakat. Pencapaian pembangunan ekonomi dapat diindikasikan dengan tingginya pertumbuhan ekonomi, meningkatnya pendapatan perkapita, luasnya kesempatan kerja, berkurangnya tingkat pengangguran dan tingkat kemiskinan. Pembangunan ekonomi merupakan suatu proses yang menyebabkan pendapatan per kapita penduduk di suatu daerah meningkat dalam jangka panjang. Kegiatan ekonomi dilaksanakan oleh pemerintah daerah bersama-sama dengan masyarakat, mengolah dan memanfaatkan sumber daya yang ada untuk merangsang perkembangan ekonomi daerah dan kesejahteraan masyarakat, antara lain tingkat pemenuhan kebutuhan masyarakat yang berasal dari berbagai produk yang dihasilkan.

Pengembangan ekonomi kerakyatan bertujuan untuk meningkatkan partisipasi masyarakat dalam berbagai aktivitas pembangunan khususnya di bidang ekonomi, peningkatan kualitas sumber daya manusia agar mampu mengolah sumber daya alam secara efisien dan berkelanjutan guna meningkatkan pandapatan dan kesejahteraan. Mendorong masyarakat, pengusaha kecil dan menengah untuk berkembang serta mampu mendukung berkembangnya ekonomi daerah dan menciptakan lapangan kerja dan kesempatan berusaha.

Arah pembangunan di Provinsi Papua sebagaimana tertuang dalam Rencana Pembangunan Jangka Menengah Daerah (RPJMD) Provinsi Papua tahun 2013-2018 (Bappeda Provinsi Papua, 2013), ditetapkan dengan maksud untuk memberikan arah dan pedoman bagi seluruh pemangku kepentingan baik pemerintah, masyarakat dan dunia usaha di dalam mewujudkan cita-cita dan tujuan pembangunan daerah yang berkesinambungan serta menitikberatkan pada pengembangan ekonomi masyarakat dipedesaan atau kampung, sebagai jawaban atas ketimpangan kehidupan masyarakat selama ini, terutama berkaitan dengan upaya pemenuhan hak-hak dasar masyarakat asli Papua yang sebagian besar berdomisili di kampung-kampung, sesuai amanat Undang-Undang Otonomi Khusus Nomor 21 Tahun 2001, pasal 65 ayat 2 yang menyebutkan bahwa "orang asli Papua berhak memperoleh kesempatan dan diutamakan untuk mendapatkan pekerjaan di wilayah Provinsi Papua berdasarkan pendidikan dan keahliannya yang diatur melalui Perdasi dan perdasus.

Tindak lanjut dari Undang-Undang Otonomi Khusus diatas, maka lahirlah Peraturan Daerah Khusus (Perdasus) Nomor 25 tahun 2013 pasal 11 ayat 1.c. yang mengatur tentang pembiayaan pengembangan ekonomi kerakyatan minimal 20 persen yang penganggarannya dialokasikan untuk perkreditan usaha ekonomi rakyat, dana bergulir, subsidi harga kebutuhan sembilan bahan pokok, dan pengembangan komoditi unggulan.

Upaya pembangunan perekonomian untuk meningkatkan pendapatan masyarakat termasuk upaya pemerataan hasil-hasil pembangunan agar dapat dirasakan semua lapisan masyarakat. Permasalahan pembangunan ekonomi selama ini di Provinsi Papua meliputi; (1) belum efektifnya pengembangan ekonomi kerakyatan untuk menunjang pendapatan keluarga berbasis hak masyarakat adat; (2) Belum efektifnya pelaksanaan RESPEK dalam memicu pertumbuhan produktivitas kampung; (3) Belum optimalnya pengembangan komoditas unggulan daerah yang memiliki potensi pasar yang luas baik dalam skala nasional maupun internasional; (4) Belum padunya pengembangan industri pariwisata daerah dengan berbagai potensi alam dan budaya yang dapat meningkatkan pendapatan masyarakat adat dan penduduk lokal; (5) Masih minimnya perlindungan terhadap hak-hak masyarakat adat atas kebudayaan dan hasil-hasilnya, yang seharusnya dapat meningkatkan pendapatan penduduk lokal; (6) Belum optimalnya peran masyarakat adat dan lembaga keagamaan dalam mengembangkan ekonomi dan pendapatan penduduk; (7) Belum adanya konsep/Rencana Aksi pengembangan ekonomi rakyat yang lebih kompehensif dan teritegrasi mulai dari tahap produksi 
sampai tahap pemasaran yang mengarah pada kesesuaian dengan kebutuhan pasar.(RPJMD Papua,2013).

Pemahaman umum tentang "ekonomi kerakyatan” adalah perekonomian yang berbasis lokal (setempat), pelaku lokal mempunyai skala usaha menengah, kecil, hingga mikro dan mempunyai bentuk usaha formal maupun nonformal. Salah satu jenis usaha yang dimaksudkan dalam pemahaman ini adalah koperasi atau yang sejenis. Jenis usaha ekonomi kerakyatan adalah biasanya terkait dengan kondisi lokal, misalnya usaha pertanian, perkebunan, peternakan, perikanan, kelautan, industri kecil atau juga disebut industri kerajinan dan makanan serta pedagangan berskala menengah hingga mikro.

Kebijakan pengembangan ekonomi kerakyatan tidak dicantumkan secara khusus pada UndangUndang Otonomi Khusus Nomor 21 Tahun 2001. Namun demikian terdapat beberapa pasal yang dapat dkaitkan dengan usaha untuk mengembangkan ekonomi kerakyatan. Pasal 42 ayat (1) Undang-Undang Otonomi Khusus tersebut menyebutkan bahwa "pembangunan perekonomian berbasis kerakyatan dilaksanakan dengan memberikan kesempatan yang seluas-luasnya kepada masyarakat adat dan/atau masyarakat setempat”. Selanjutnya disebutkan juga bahwa “ Penanam modal yang melakukan investasi di wilayah Provinsi Papua harus mengakui dan dan menghormati hak-hak masyarakat adat setempat”. Sementara itu pada bagian akhir pada pasal 42 tersebut disebutkan bahwa "pemberian kesempatan berusaha dilakukan dalam kerangka pemberdayaan masyarakat adat agar dapat berperan dalam perekonomian seluasluasnya.

Ekonomi kerakyatan tumbuh secara natural karena adanya sejumlah potensi ekonomi disekelilingnya, (Benu, 2002: 27). Ekonomi rakyat mulanya berkembang tanpa adanya insentif apapun, atau dengan kata lain hanya mengandalkan naluri usaha dan dukungan potensi sumber daya alam, sumber daya manusia serta peluang pasar. Perlu dipahami bahwa dalam ruang ekonomi nasional pun terdapat sejumlah aktor ekonomi (konglomerat) dengan bentuk usaha yang kontras dengan apa yang diragakan oleh sebagian besar pelaku ekonomi rakyat. Memiliki modal yang besar, mempunyai akses pasar yang luas, menguasai usaha dari hulu hingga hilir, menguasai teknologi produksi dan manajemen usaha moderen.

Ekonomi kerakyatan menurut Mubyarto adalah "sistem ekonomi nasional Indonesia berasaskan kekeluagaan, berkedaulatan rakyat, bermoral Pancasila dan menunjukkan pemihakan pada ekonomi rakyat”. Selanjutnya Mubyarto berpendapat bahwa memberdayakan ekonomi rakyat berarti melaksanakan demokrasi ekonomi yaitu produksi dikerjakan oleh semua dan di bawah pimpinan dan kepemilikan anggota-anggota masyarakat (Mubyarto,2002:45). Menurut Indra Gunawan (2012 :56 ), pelaksanaan ekonomi kerakyatan paling tidak memiliki lima ciri sebagai berikut: (1) Prinsip keadilan dan demokrasi ekonomi, kepedulian terhadap yang lemah, tanpa membedakan suku, agama, dan gender; (2). Pemihakan, pemberdayaan, dan perlindungan terhadap yang lemah (UMKM, petani, dan nelayan kecil mendapat prioritas); (3). Penciptaan iklim persaingan usaha yang sehat (UMKM diberi pelatihan, akses pada permodalan, informasi pasar dan teknologi tepat guna); (4).Menggerakkan ekonomi daerah pedesaan termasuk daerah terpencil, daerah minus, dan daerah perbatasan; (5). Pemanfaatan dan penggunaan tanah dan sumber daya alam secara transparan, adil, dan produktif.

Sebagai salah satu modal utama pembangunan suatu daerah, maka potensi ekonomi sangat perlu dikembangkan. Pengembangan ekomomi kerakyatan dengan memanfaatkan potensi UMKM selama ini belum memberikan dampak yang signifikan bagi kesejahteraan masyarakat. Permasalahan utama dalam studi ini adalah mengapa pengembangan ekonomi kerakyatan di Provinsi Papua belum belum efisien dan memberikan dampak yang signifikan bagi kehidupan masyarakat Papua yang ditandai dengan masih tingginya angka kemiskinan 31,13 persen (tertinggi secara nasional) dan rendahnya Indeks Pembangunan Manusia (IPM) sebesar 65,9 persen atau berada di urutan terbawah secara nasional, Bappeda Papua (2014), sehingga perlu dicari solusi pemecahan melalui suatu strategi pengembangan.

Adapun yang menjadi tujuan dari studi ini adalah (1) melihat sejauh mana pengembangan ekonomi kerakyatan di Provinsi Papua, dan (2) merumuskan strategi pengembangan ekonomi kerakyatan di Provinsi Papua. Sementara itu manfaat dari studi ini adalah untuk memberikan sumbangan pemikiran bagi pemerintah Provinsi Papua secara khusus dalam upaya pengembangan ekonomi kerakyatan, serta sebagai referensi di kemudian hari untuk penelitian yang sejenis.

\section{METODE}

Jenis penelitian ini bersifat deskriptif, yaitu dengan menghimpun data untuk menjawab permasalahan yang ada. Penelitian ini bertujuan untuk mendeskripsikan atau menjelaskan sesuatu hal apa adanya.

Teknik Pengumpulan Data yang digunakan untuk mengumpulkan data dalam kajian iniadalah

1. Focus Group Discussion (FGD), yaitu diskusi mendalam untuk menggali informasi-informasi penting terkait masalah yang di teliti

2. Interview, yaitu cara pengumpulan data yang dilakukan dengan wawancara atau tanya jawab 
yang dilakukan secara langsung terhadap responden yang menjadi sampel penelitian atau responden yang ada kaitannya dengan studi ini.

3. Studi Pustaka, yaitu cara pengumpulan data dengan mempelajari pustaka yang sesuai dengan masalah yang dikaji.

Untuk merumuskan strategi pengembangan ekonomi kerakyatan di Provinsi Papua maka digunakan Analsis SWOT, yaitu analisis yang terdiri dari Strength (kekuatan), Weaknes (Kelemahan), Opportunity (kesempatan), dan Threat (ancaman) yang merupakan suatu analisis mengenai kekuatan dan kelemahan yang dimiliki unit penelitian, yang dilakukan melalui telaah terhadap kondisi internal, serta analisis mengenai peluang dan ancaman yang dihadapi unit penelitian yang dilakukan melalui telaah terhadap kondisi eksternal.Setelah diperoleh berbagai faktor kunci eksternal dan internal yang dituangkan dalam analisis SWOT pada Tabel 1.
(Kompas, Selasa, 2/1/2007) berdasarkan skala usaha, struktur ekonomi Indonesia terbukti didominasi oleh UMKM. Untuk itu maka dalam perkembangannya, UMKM di Provinsi Papua juga mengalami peningkatan dari tahun ke tahun yang ditandai dengan meningkatnya jumlah usaha, tenaga kerja yang terserap, nilai investasi dan nilai produksi, sehingga diharapkan dapat mendukung pengembangan ekonomi kerakyataan di Provinsi Papua. Berikut ini dapat terlihat didalam Tabel 2 perkembangan jumlah UMKM di Provinsi Papua.

Selain perkembangan jumlah UMKM di atas, menurut data dari BPS Provinsi Papua, tahun 2013, di mana jumlah UMKM terbanyak terdapat di Kota Jayapura dengan jumlah usaha sebanyak 768 unit, sementara jumlah usaha terkecil terdapat di Kabupaten Puncak Jaya sebanyak 21 unit usaha bahkan terdapat beberapa kabupaten pemekaran yang belum memiliki UMKM. Berdasarkan perbandingan jumlah usaha di kedua

Tabel .1. Analisis SWOT

\begin{tabular}{ccc}
\hline Internal/Eksternal & Kekuatan (S) & Kelemahan (W) \\
\hline Peluang (O) & Strategi (SO) & Strategi (WO) \\
Ancaman (T) & Strategi (ST) & Strategi (WT) \\
\hline
\end{tabular}

Tabel.2. Perkembangan Jumlah UMKM Provinsi Papua Tahun 2013

\begin{tabular}{|c|c|c|c|c|}
\hline Tahun & $\begin{array}{l}\text { Jumlah Industri } \\
\text { Kecil /UMKM }\end{array}$ & Tenaga Kerja & NilaI Investasi & Nilai Produksi \\
\hline 2009 & 3.421 & 14.224 & 32.866 .622 & 102.829 .000 \\
\hline 2010 & 3.609 & 14.690 & 40.567 .920 & 114.642 .308 \\
\hline 2011 & 3.838 & 15.307 & 43.044 .900 & 116.612 .875 \\
\hline 2012 & 4.151 & 16.705 & 47.910 .170 & 120.043 .800 \\
\hline
\end{tabular}

Sumber : Dinas Perindustrian, Perdagangan, Koperasi dan UKM Provinsi Papua

Menurut Haffianto (2009), analisis SWOT merupakan sebuah metode perencanaan strategis yang digunakan untuk mengevaluasi kekuatan, kelemahan, peluang dan ancaman dalam suatu proyek atau usaha spekulasi bisnis. Proses ini melibatkan penentuan tujuan yang spesifik dari spekulasi bisnis atau proyek dan mengidentifikasi faktor eksternal dan internal yang mendukung dan tidak dalam mencapai tujuan tersebut.

\section{HASIL DAN PEMBAHASAN}

\section{Perkembangan Usaha Mikro Kecil Menengah (UMKM) Provinsi Papua}

Upaya pengembangan ekonomi kerakyatan tidak terlepas dari bagaimana mengembangkan potensi ekonomi yang di anggap dapat melibatkan masyarakat banyak. Kebijakan pemerintah untuk membangun UMKM dirasakan sangat menunjang pengembangan ekonomi kerakyatan. Menurut Kepala BPS Pusat, wilayah tersebut menggambarkan bahwa pengembangan ekonomi kerakyatan melalui UMKM juga belum secara merata berkembang di seluruh pelosok Provinsi Papua. Untuk itu maka diperlukan adanya kebijakan melalui pembinaan dan pelatihan yang kontinyu serta dukungan pemerintah untuk mengatasi permasalahan atau faktor-faktor yang berpengaruh terhadap perkembangan usaha masyarakat. Berdasarkan hasil studi melalui wawancara dengan beberapan responden kunci (pelaku usaha asli Papua) diketahui bahwa faktor-faktor yang berpengaruh terhadap pengembangan ekonomi kerakyatan di Provinsi Papua melalui UMKM masih bersifat masalah klasik seperti kekurangan modal usaha, peralatan yang masih sederhana, kurangnya pembinaan, masalah pemasaran, rendahnya kualitas SDM dan sebagainya.

Berdasarkan data di atas, terlihat bahwa perkembangan jumlah usaha UMKM dari tahun ke tahun mengalami peningkatan, namun peningkatan 
tersebut belum memberikan dampak yang signifikan bagi kehidupan masyarakat di Provinsi Papua secara umum yang di tandai dengan masih tingginya jumlah penduduk miskin. Hal ini disebabkan karena salain jenis usaha yang masih terbatas serta kualitas dan kuantitas produksi yang masih rendah sehingga kadang kala hasil produksi tersebut masih kalah bersaing dengan hasil produksi dari luar Papua yang didatangkan untuk menunjang kebutuhan masyarakat di Papua. Sebagai contoh adalah produksi pertanian seperti sayur mayur (kol, wortel, kentang dan lainnya), produksi perikanan seperti ikan mujair, bandeng dan jenis ikan lainnnya juga masih didatangkan dari luar Papua.

Berdasarkan hasil studi juga diketahui bahwa selain permasalahan di atas, masalah penganekaragaman (diversity product) usaha dan pemanfaatan Teknologi Tepat Guna (TTG) juga belum berjalan dengan baik (Mollet, 2012). Pelaku usaha ekonomi kerakyatan di provinsi Papua juga masih didominasi oleh masyarakat pendatang yang sudah lama berdomisili di Papua dengan kualitas SDM yang lebih baik jika dibandingkan dengan masyarakat pribumi yang secara naluri juga masih sangat rendah dalam berusaha, rendahnya naluri atau jiwa kewirausahaan ini selain karena tingkat pendidikan masyarakat yang rata-rata masih rendah juga dipengaruhi oleh budaya setempat sehingga berdampak terhadap produktifitas mereka.

\section{Penganekaragaman Usaha dan Pemanfaatan Teknologi Tepat Guna (TTG)}

Dari hasil studi juga diketahui bahwa selain permasalahan diatas, masalah penganekaragaman usaha (diversity product) dan pemanfaatan teknologi tepat guna (TTG) juga belum berjalan dengan baik. Pelaku usaha ekonomi kerakyatan di provinsi Papua juga masih didominasi oleh masyarakat pendatang yang sudah lama berdomisili di Papua dengan kualitas SDM yang lebih baik jika dibandingkan dengan masyarakat pribumi yang secara naluri juga masih sangat rendah dalam berusaha, rendahnya naluri atau jiwa kewirausahaan ini selain karena tingkat pendidikan masyarakat yang rata-rata masih rendah juga dipengaruhi oleh budaya setempat sehingga berdampak terhadap produktifitas mereka.

Upaya pengembangan usaha ekonomi kerakyatan dapat juga dilaksanakan dengan penganekaragaman usaha dan pemanafaatan Teknologi Tepat Guna (TTG). Sebagai contoh kasus, di mana pelaku usaha masyarakat asli Papua pada umunya hanya sebagai penjual pinang, ikan asar, ikan segar, jualan sayur, roti bakar, keladi bakar, buah-buahan lokal dan sebagainya yang sudah turun temurun dengan pemasaran pun masih terbatas pada pasar-pasar tradisionil. Kesan yang didapai bahwa tidak ada upaya penganekaragaman usaha dari para pelaku usaha ini belum berjalan dengan baik, misalnya ikan segar jika dengan memanfaatkan teknologi tepat guna (TTG) maka akan diolah selain menjadi ikan asar, juga dapat dikembangkan menjadi abon ikan, kerupuk, bakso, ikan asin dan lainnya dan diupayakan untuk dapat bersaing dengan produk lain di pasar moderen (super market) sehingga akan memberikan nilai tambah dari produk tersebut, begitu juga dengan potensi ekonomi lainnya seperti sagu, buah merah, buah matoa dan sebagainya yang merupakan potensi khas Papua.

Permasalahan yang dihadapi pelaku usaha secara umum maupun khususnya masyarakat asli Papua dalam penganekaragaman usaha dan pemanfaatan TTG juga masih perlu dukungan pemerintah dan swasta serta lembaga keuangan/perbankan. Salah satu faktor yang menghambat masyarakat pelaku ekonomi kerakyatan untuk berkembang adalah faktor peralatan usaha dan akses pasar yang masih sangat terbatas selain modal usaha. Untuk itu pemerintah perlu menyiapkan regulasi yang secara khusus mengatur mekanisme ini dengan cara memfasilitasi atau meminta dukungan sektor swasta/pengusaha besar dalam bentuk mitra usaha untuk mendukung pelaku ekonomi rakyat dari alat produksi (TTG) sampai pada menyiapkan lokasi secara khusus bagi hasil usaha masyarakat untuk dapat akses pemasaran ke pasar-pasar moderen (super market). Salin itu dapat juga melalui peningkatan wira usaha baru bagi masyarakat asli sebagaimana amanat Undang-undang otonomi khusus (OTSUS) dan penjabaran dari RPJMD provinsi Papua tahun 20132018.

\section{Kualitas dan Kuantitas Produk Usaha yang Berkelanjutan}

Upaya pengembangan ekonomi kerakyatan di provinsi Papua memang menghadapi banyak permasalahan. Dari hasil studi juga diketahui bahwa salah satu permasalahan utama adalah kualitas dan kuantitas produk masyarakat pelaku ekonomi kerakyatan baik berupa UMKM maupun yang lainnya. Salin karena kualitas yang kalah bersaing dengan produk usaha dari luar Papua. Juga masalah kemampuan produksi yang berkelanjutan. Sebagai contoh kasus adalah petani rumput laut di Distrik Sariwanderi Kabupaten Yapen Papua, yang tidak mampu menyediakan produk rumput laut secara berkelanjutan kepada salah satu perusahaan yang dijadikan mitra usaha. Sehingga pada akhirnya usaha ini tidak dapat berjalan dengan baik. Begitu juga dengan usaha ikan bandeng di Holtekam Muara Tami Kota Jayapura yang akhirnya tidak mampu bersaing dengan produk ikan bandeng produksi dari luar Papua karena kalah bersaing dalam hal kualitas dan harga. Ini semua perlu menjadi perhatian serius bagi pemerintah 
daerah dalam kebijakan terkait pembinaan dan pendampingan yang kontinyu serta dukungan modal usaha yang maksimal, karena sebenarnya kita di Papua memiliki potensi yang sangat besar untuk dikembangkan. Dan jangan kita hanya sebatas pada bangga dengan potensi tersebut tapi bagaimana mengembangkannya.

\section{Strategi Pengembangan Ekonomi Kerakyatan di Provinsi Papua}

Perumusan strategi pengembangan ekonomi kerakyatan di provinsi Papua dengan menggunakan analisis SWOT untuk menggambarkan bagaimana peluang dan ancaman (faktor eksternal) yang dihadapi oleh masyarakat yang disesuaikan dengan kelemahan dan kekuatan (faktor internal) yang masing-masing dari kedua faktor tersebut memberikan danpak positif dan negatif. Pembahasan tentang kedua faktor tersebut dapat terlihat pada Tabel 3 . otonomi khusus serta program pemberdayaan masyarakat kampung melalui Prospek, dan adanya tenaga pendamping yang disiapkan pemerintah. Selain faktor kekuatan internal di atas, Provinsi Papua memiliki beberapa kelemahan yang perlu dicarikan solusi pemecahan. Kelemahan utama yang diketahui dari hasil penelitian adalah rendahnya tingkat pendidikan masyarakat formal. Selain itu kurangnya modal usaha serta peralatan kerja yang masih sederhana juga menjadi kelemahan dalam masyarakat. Sementara itu kelemahan lain adalah sebagian besar masyarakat adalah petani subsisten dengan pola pertanian masih sederhana, rendahnya kualitas dan kuantias hasil produk, kurangnya aneka produk yang dikembangkan serta belum memanfaatkan TTG, kekurangan modal usaha serta peralatan masih sederhana, kualitas dan kuantitas tenaga pendamping masih rendah, dan belum berkembangnya koperasi/KUD.

\section{Tabel .3. Matrix Internal dan Eksternal Pengembangan Ekonomi Kerakyatan}

\begin{tabular}{|c|c|c|c|}
\hline \multicolumn{2}{|c|}{ Faktor internal } & \multicolumn{2}{|c|}{ Faktor Eksternal } \\
\hline Kekuatan & Kelemahan & Peluang & Ancaman \\
\hline 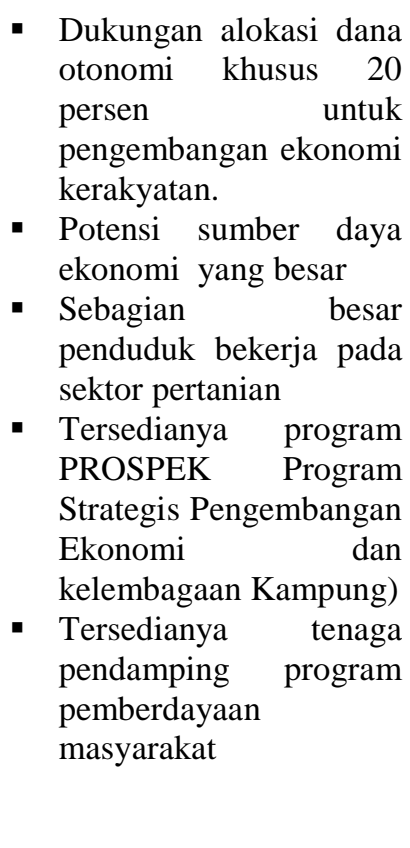 & 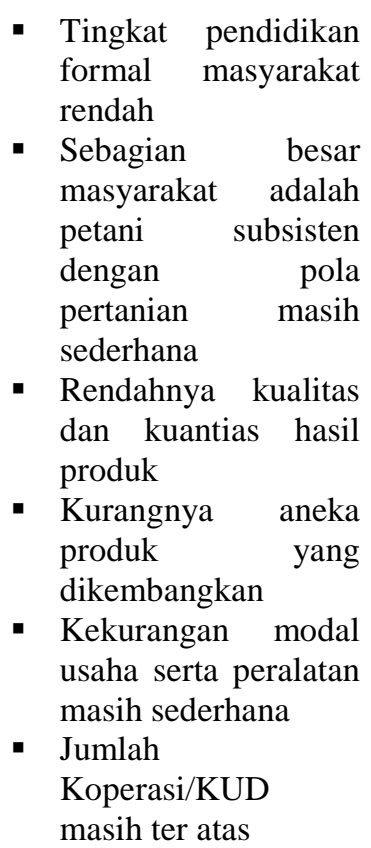 & 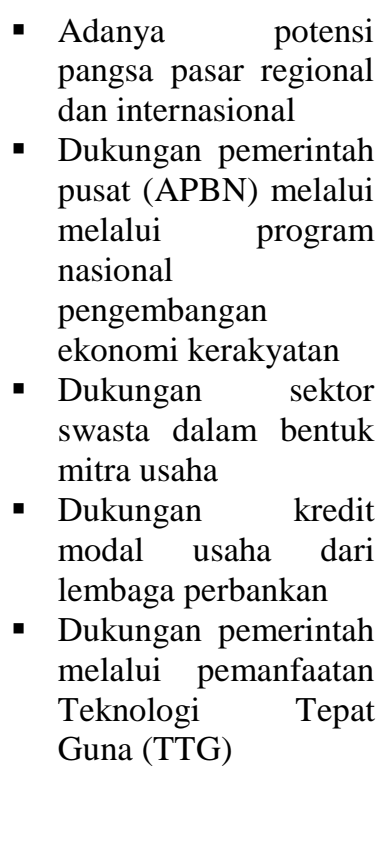 & 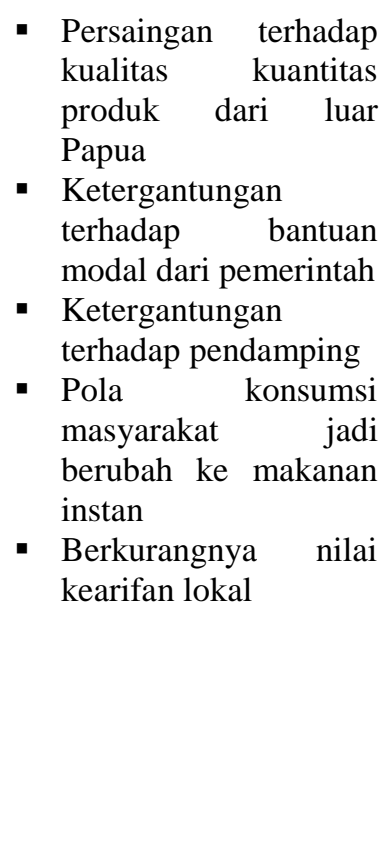 \\
\hline
\end{tabular}

\section{Sumber : Data primer (diolah)}

Analisis faktor internal menunjukkan bahwa dalam pengembangan ekonomi kerakyatan terdapat kekuatan dan kelemahan. Faktor kekuatan yaitu tersedianya potensi sumber daya alam ekonomi yang cukup besar, sebagian besar masyarakat bekerja di sektor pertanian. Disamping itu dukungan dana
Selanjutnya untuk merumuskan strategi pengembangan ekonomi kerakyatan di Provinsi Papua maka berikut ini disajikan matrix SWOT pada Tabel 4. 
Tabel 4. Strategi Pengembangan Ekonomi Kerakyatan

\begin{tabular}{|c|c|c|}
\hline EKSTERNAL & 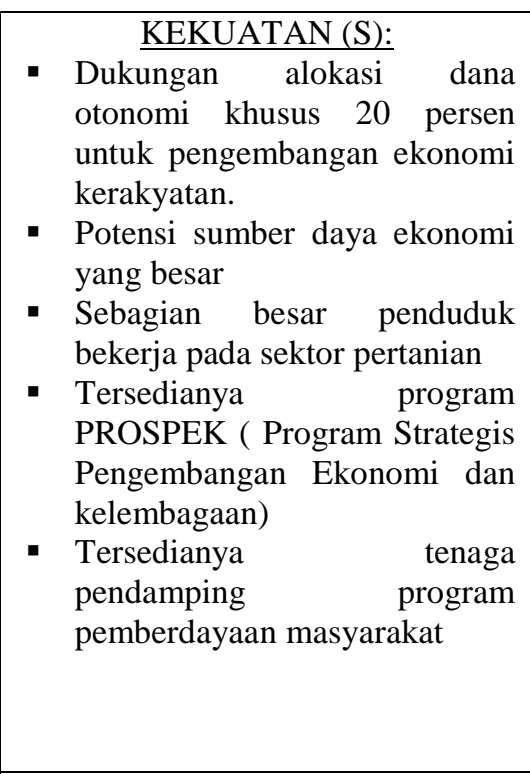 & 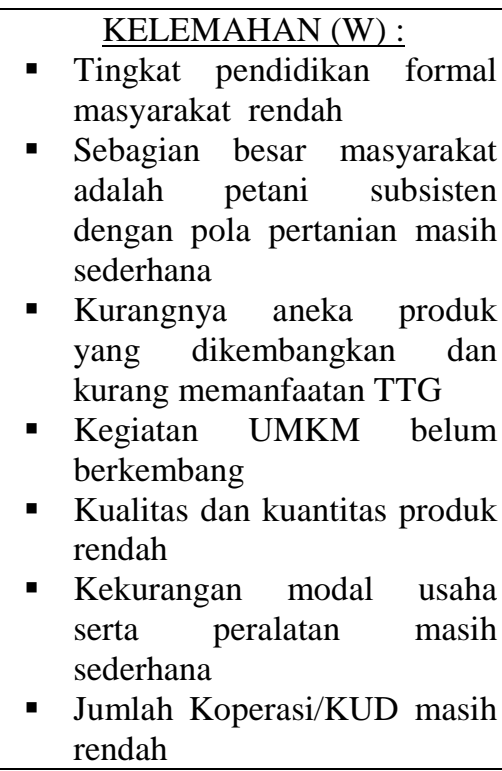 \\
\hline 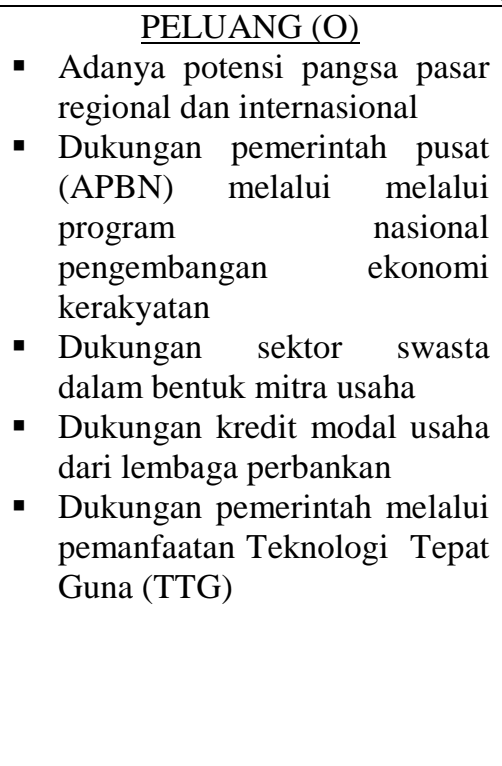 & $\begin{array}{l}\text { STRATEGI (SO): } \\
\text { - Peningkatan kualitas dan } \\
\text { kuantitas produk lokal agar dapat } \\
\text { bersaing dengan pasar regional } \\
\text { dan internasional } \\
\text { - Pemberian dana stimulan untuk } \\
\text { modal usaha bagi para pelaku } \\
\text { ekonomi rakyat dengan } \\
\text { memanfaatkan dana OTSUS, dan } \\
\text { APBN PN } \\
\text { - Peningkatan SDM pelaku } \\
\text { ekonomi rakyat dan petani } \\
\text { melalui dukungan sektor swasta } \\
\text { (mitra usaha) dan permodalan } \\
\text { dari lembaga perbankan }\end{array}$ & $\begin{array}{l}\text { STRATEGI (WO): } \\
\text { - Meningkatan kuallitas SDM } \\
\text { pelaku ekonomi rakyat melalui } \\
\text { pendidikan non formal/pelatihan } \\
\text { - Pemberian modal usaha dan } \\
\text { peralatan pertanian dengan } \\
\text { memanfaatkan teknologi tepat } \\
\text { guna (TTG) } \\
\text { - Meninkatkan kualitas dan } \\
\text { kuantitas produk melalui } \\
\text { penganekaragaman produk } \\
\text { (diversity product) } \\
\text { - Meningkatkan peran UMKM } \\
\text { dan koperasi sampai ke seluruh } \\
\text { kabupaten/kota } \\
\text { - Pemanfatan dana program } \\
\text { pemberdayaan masyarakat } \\
\text { (Prospek) untuk kegiatan } \\
\text { ekonomi produktif }\end{array}$ \\
\hline \begin{tabular}{llr}
\multicolumn{3}{c}{ ANCAMAN (T) } \\
- & Persaingan terhadap kualitas \\
kuantitas produk dari luar \\
Papua & \\
- & Ketergantungan & terhadap \\
& bantuan modal & dari \\
pemerintah & \\
- & Ketergantungan & terhadap \\
& pendamping & \\
- & Berkurangnya nilai & kearifan \\
& lokal
\end{tabular} & $\begin{array}{l}\text { STRATEGI (ST): } \\
\text { - Meningkatkan kualitas dan } \\
\text { kuantitas produk lokal yang } \\
\text { berdaya saing } \\
\text { - Pembinaan yang berkelanjutan } \\
\text { agar masyarakat tidak selalu } \\
\text { mengantungkan pada bantuan } \\
\text { modal pemerintah } \\
\text { - Pendidikan dan pelatihan bagi } \\
\text { pelaku ekonomi kerakyatan } \\
\text { agar tidak tergantung pada } \\
\text { tenaga pendamping }\end{array}$ & \begin{tabular}{ll}
\multicolumn{3}{c}{ STRATEGI (WT): } \\
- & Meningkatkan kualitas dan \\
kuatitas tenaga pendamping \\
- & Peningkatan r kapasitas \\
masyarakat akan pentingnya \\
pembangunan & yang \\
berkelanjutan melalui nilai & kearifan lokal
\end{tabular} \\
\hline
\end{tabular}

Sumber : Data Primer (diolah)Sumber : Data Primer (diolah) 
Selanjutnya berdasarkan matrix eksternal dan internal, maka dapat disusun atau dirumuskan strategi pengembangan ekonomi kerakyatan di Provinsi Papua sebegai berikut:

1. Strategi S-O

a. Peningkatan kualitas dan kuantitas produk lokal agar dapat bersaing dengan pasar regional dan internasional

b. Pemberian dana stimulan untuk modal usaha bagi para pelaku ekonomi rakyat dengan memanfaatkan dana OTSUS, dan APBN

c. Peningkatan SDM pelaku ekonomi rakyat dan petani melalui dukungan sektor swasta (mitra usaha) dan permodalan dari lembaga perbankan

2. Strategi W-O

a. Meningkatan kuallitas SDM pelaku ekonomi rakyat melalui pendidikan non formal/pelatihan

b. Pemberian modal usaha dan peralatan produksi dengan memanfaatkan teknologi tepat guna (TTG)

c. Meningkatkan kualitas dan kuantitas produk melalui penganekaragaman produk (diversity product)

d. Meningkatkan peran UMKM dan koperasi sampai ke seluruh kabupaten/kota dalam mendukung pengembangan ekonomi kerakyatan

3. Strategi S-T

a. Meningkatkan kualitas dan kuantitas produk lokal yang berdaya saing

b. Pembinaan yang berkelanjutan agar masyarakat tidak selalu mengantungkan pada bantuan modal pemerintah

c. Pendidikan dan pelatihan bagi pelaku ekonomi kerakyatan agar tidak tergantung pada tenaga pendamping

4. Strategi W-T :

a. Meningkatkan kualitas dan kuatitas tenaga pendamping

b. Peningkatan kapasitas masyarakat akan pentingnya pembangunan yang berkelanjutan melalui nilai-nilai kearifan lokal

\section{KESIMPULAN}

Berdasarkan hasil studi dan pembahasan, maka dapat disimpulkan beberapa hal sebagai berikut :

Pengembangan ekonomi kerakyatan di provinsi Papua belum dapat dilaksanakan secara maksimal karena dipengaruhi oleh beberapa kelemahan dan kendala teknis lainnya seperti kekurangan modal usaha, peralatan yang masih sederhana, sulitnya akses pasar dan lemahnya jiwa kewiraushaan khususnya bagi masyarakat/pengusaha asli Papua. Pengembangan ekonomi kerakyatan dapat dilakukan dengan memanfaatkan peran UMKM dan Kopersi/KUD karena masyarakat dengan mudah dapat dilibatkan dalam kedua wadah ekonomi rakyat tersebut.

Pengembangan ekonomi kerakyatan dapat dilakukan dengan: Peningkatan kualitas dan kuantitas produk lokal agar dapat bersaing dengan pasar regional dan internasional, pemberian dana stimulan untuk modal usaha bagi para pelaku ekonomi rakyat dengan memanfaatkan dana OTSUS, dan APBN, Peningkatan SDM pertanian melalui dukungan sektor swasta (mitra usaha) dan permodalan dari lembaga perbanka. Untuk mengatasi kelemahan yang dimiliki dalam pengembangan ekonomi kerakyatan maka dapat dilakukan melalui: Meningkatan kuallitas SDM pelaku ekonomi rakyat melalui pendidikan non formal/pelatihan, pendidikan dan pelatihan yang berkelanjutan bagi para tenaga pendamping, pemberian modal usaha dan peralatan pertanian dengan memanfaatkan teknologi tepat guna (TTG), meningkatkan peran UMKM dan koperasi sampai ke seluruh kabupaten/kota, Pemanfatan dana program untuk kegiatan ekonomi produktif

Kebijakan pengembangan ekonomi kerakyatan memiliki peluang berupa meningkatkanya kualitas dan kuantitas produk lokal yang berdaya saing, masyarakat tidak selalu mengantungkan pada bantuan modal pemerintah, pelaku ekonomi kerakyatan tidak selamanya tergantung pada tenaga pendamping.

Sementara itu saran atau rekomendasi dari studi ini adalah: Program pengembangan ekonomi kerakyatan sebaiknya dilakukan melalui pemenfaatan sarana kelembagaan ekonomi berupa UMKM dan Koperasi/KUD. Pengembangan ekonomi kerakyatan dilakukan dengan memanfaatkan teknologi tepat guna (TTG) dan penganekaragaman produk agar kulaitas dan kuantitas produk dapat lebih ditingkatkan

Pembinaan dan pendampingan yang kontinyu agar pelaku ekonomi rakyat dapat mandiri dan tidak menggantungkan pada bantuan pemerintah. Dalam pengembangan ekonomi kerakyatan tetap memperhatikan nilai-nilai kearifan lokal agar terciptanya pembangunan yang berkelanjutan 


\section{Daftar Pustaka}

Bambang, Haffianto, 2009, Perencanaan Sistem. Fakultas Ekonomi Universitas Indonesia, Jakarta.

Bappeda Provinsi Papua, 2013. Rencana Pembangunan Jangka Menengah Daerah (RPJMD) 2013-2018. Jayapura.

Bappeda Provinsi Papua, 2013. Profil Pembangunan Papua. Jayapura

BPS Papua , 2014, Papua Dalam Angka, Kerjasama Bappeda Papua dan BPS Papua. Jayapura.

Benu, Frederik.2002. Ekonomi Kerakyatan dan Pemberdayaan Ekonomi Rakyat: suatu kajian konseptual. Makalah pada seminar pemberdayaan ekonomi rakyat di Provinsi NTT, Kupang.

Badan Pusat Statistik, 2011, Provinsi Papua Dalam Angka, Jayapura
Gunawan, Indra 2012, FKIP Universitas Sanata Dharma. Yogyakarta

Kompas, Selasa, 2/1/2007.

Mubyarto (2002), Ekonomi Kerakyatan dalam Era Globalisasi, Jurnal Ekonomi Kerakyatan, Yogyakarta

Mollet, Julius Ary, 2012. Studi Ekonomi Kerakyatan Nelayan di Weref Kota Jayapura. Jayapura

Suratno dan Lincolin Arsyad. 1998. Metodologi Penelitian. AMP-YKPN.Yaogyakarta.

Sukirno, Sadono. 1981. Pengantar Teori Makro Ekonomi. Penerbit FE-UI. Jakarta

Sekretariat Negara, 2001, Undang-Undang Nomor 21 Tentang Pemberian Otonomi Khusus bagi Provinsi Papua. Jakarta.

Sekretariat Daerah Provinsi Papua, 2013. Perdasus Nomor 25 Tahun 2013 tentang Pengelolaan Dana Otonomi Khusus. Jayapura 
260 | Jurnal Bina Praja | Volume 7 No. 3 Edisi September 2015 : 251 - 260 